\title{
Azaspiracid accumulation, detoxification and biotransformation in blue mussels (Mytilus edulis) experimentally fed Azadinium spinosum
}

\author{
Thierry Jauffrais ${ }^{a, *}$, Claire Marcaillou ${ }^{a}$, Christine Herrenknecht $^{b}$, Philippe Truquet ${ }^{a}$, Véronique Séchet ${ }^{a}$, \\ Elodie Nicolau ${ }^{a}$, Urban Tillmann ${ }^{c}$, Philipp Hess ${ }^{a, *}$
}

\author{
${ }^{a}$ IFREMER, Laboratoire EMP/PHYC, Rue de l'lle d'Yeu, 44311 Nantes, France \\ ${ }^{\mathrm{b}}$ Nantes Atlantique Université, MMS EA2160, 9 rue Bias, 44035 Nantes, France \\ ${ }^{c}$ Alfred Wegener Institute, Am Handelshafen 12, D-27570 Bremerhaven, Germany \\ *: Corresponding authors : Thierry Jauffrais, email address : Thierry.Jauffrais@ifremer.fr ; \\ Philippe Hess, Tel.: +33 240374257 ; fax: +332403740 26 ; email address : Philipp. Hess@ifremer.fr
}

\begin{abstract}
:
Azadinium spinosum (Elbrächter and Tillmann), a small marine dinoflagellate, has been recently described as a de novo producer of azaspiracid-1 and -2 (AZA1 and -2) diarrhoeic toxins. A culture of A. spinosum was established in our laboratory and optimised for pilot-scale production of this organism, to evaluate and understand AZA1 and -2 accumulation and biotransformation in blue mussels (Mytilus edulis) fed with $A$. spinosum.
\end{abstract}

Adult mussels were continuously exposed to $A$. spinosum over 1 week in $160 \mathrm{~L}$ cylindrical conical tanks. Three different diets were tested for contamination: 5000,10000 cells $\mathrm{mL}^{-1}$ of $A$. spinosum and a mixture of 5000 cells mL $\mathrm{m}^{-1}$ of $A$. spinosum with $5000 \mathrm{cells} \mathrm{mL}^{-1}$ of Isochrysis aff. galbana (T-Iso, CCAP 927/14). During the subsequent period of detoxification (2 weeks), contaminated mussels were continuously fed with 5000 cells $\mathrm{mL}^{-1}$ of T-/so. Kinetics of accumulation, detoxification and biotransformation were evaluated, as well as the toxin distribution and the effect of $A$. spinosum on mussel digestive gland tubules.

$M$. edulis fed on $A$. spinosum in the three tested conditions; this finding confirmed our recent experiments feeding $A$. spinosum to mussels. The original algal toxins AZA1 and -2 , as well as mussel metabolites AZA3 to $12,-17,-19,-21$ and -23 were found during these trials. After as little as $6 \mathrm{~h}$, azaspiracid contents in mussels reached the EU regulatory limit, and metabolites were observed in all conditions at approximately $25 \%$ of the total AZA content. This fraction exceeded $50 \%$ after $24 \mathrm{~h}$, and continued to increase until the end of the study. AZA17 and -19 were found to be the main metabolites, with AZA17 concentrations estimated in the same order of magnitude as that of the main algal toxin, AZA1.

\section{Highlights}

Azadinium spinosum was cultured and fed to blue mussels (Mytilus edulis). Mussels accumulated azaspiracids in less than $6 \mathrm{~h}$ to greater than legal limit. Biotransformation of algal toxins into shellfish metabolites was also rapid with $>25 \%$ metabolites observed after $6 \mathrm{~h}$. - Detoxification speed was comparable with other lipophilic toxins (half-life ca. 11 days). - Azaspiracids-6, -17 and -19 should also be considered in legislation.

Keywords: Azaspiracid ; Azadinium spinosum ; Marine biotoxins ; AZA ; Tissue distribution ; Histology ; Bivalve molluscs ; Liquid chromatography coupled to tandem mass spectrometry 


\section{Introduction}

The group of phycotoxins now known as Azaspiracids (AZAs) were first detected in Ireland (McMahon and Silke, 1996), when mussels harvested from Killary Harbour and exported to the Netherlands in 1995 caused human intoxications due to these toxins. The symptoms were similar to diarrhetic shellfish poisoning (DSP), but, only very low concentration of okadaic acid and dinophysistoxin-2 were found (McMahon and Silke, 1996). Three years later, the toxin was isolated and named azaspiracid (Satake et al., 1998). Later on, the structure of the molecule was revised thanks to clarifications given by total synthesis of azaspiracid-1 (Nicolaou et al., 2004). Subsequently, AZA2-5 were purified and identified using nuclear magnetic resonance (NMR) and liquid chromatography coupled to tandem mass spectrometry (LC-MS/MS) (Ofuji et al., 2001; Ofuji et al., 1999) and AZA6-32 (Diaz Sierra et al., 2003; James et al., 2003)(McCarron et al., 2009; Rehmann et al., 2008) only using LC-MS/MS. Despite repeated AZA occurrences, twelve years were necessary until the discovery of the primary producer, the dinoflagellate Azadinium spinosum (Elbrächter and Tillmann, strain 3D9) (Krock et al., 2008; Krock et al., 2009; Tillmann et al., 2009). This micro-alga produces AZA1 and -2 and belongs to a new genus, species of which have now been identified in Scotland (Krock et al., 2008; Tillmann et al., 2009), Denmark (Tillmann et al., 2011), Ireland (Salas et al., 2011), Italy and France (Siano and Nézan, personal communication), Argentina (Akselman and Negri, 2010), Mexico (Hernandez-Becerril et al., 2010) and recently in Korea (Potvin et al., 2011). In Ireland, AZA is a recurrent problem as mussels frequently accumulate this group of toxins to reach concentrations above the regulatory limit in shellfish, i.e. $160 \mu \mathrm{g}$ AZA1-equivalents per $\mathrm{kg}$ of shellfish flesh (Salas et al., 2011), thus causing important economic losses to shellfish industry and potential threat to consumers. In other countries, AZAs are carefully monitored as these toxins were also found in Europe, Morocco, America as well as Japan (Alvarez et al., 2010; Amzil et al., 2008; Furey et al., 2010; Magdalena et al., 2003a; Taleb et al., 2006; Twiner et al., 2010; Ueoka et al., 2009).

Direct accumulation of $A$. spinosum by blue mussels was recently demonstrated for the first time (Salas et al., 2011). Blue mussels were able to feed on $A$. spinosum, and the presence of AZA1 and -2 metabolites was confirmed after $24 \mathrm{~h}$ exposition to the microalga (AZA3, -17 and -19) with AZA17 as a major metabolite. This last point poses a problem to public health as AZA17 and -19 are not explicitly regulated in the EU, even though it was shown to form AZA3 and -6 , respectively, when mussels are cooked (McCarron et al., 2009). Current EU regulation (Anonymous, 2005) only includes AZA1-3, as they were the main analogues identified in cooked mussels in 2001 when the first toxin-specific regulation was formulated. Furthermore, AZA1 toxicity equivalent factors (TEF) of 1.8 and 1.4 were given for AZA2 and 3 (Ofuji et al., 1999) whereas for AZA4 and -5 the factor was 2.5 and 5 time less toxic than AZA1 (Ofuji et al., 2001). Concerning the relative in vitro potency of AZA6, it appears to be not unlike that of AZA1 (Dr. M. Twiner, personal communication). Thus, a provisional TEF of 1 was attributed to AZA6 as a crude estimate of its toxic potency. Since the current guideline by the EU reference laboratory prescribes analysis of raw shellfish tissues, AZA17 and -19 may be seen as a risk to human health, as the total AZA content might be significantly underestimated. In Ireland, maximum concentrations of monitored AZAs in bivalve molluscs between 2003 and 2010 were reviewed (Salas et al., 2011) and showed records above regulatory limit (0.16 mg. $\mathrm{kg}^{-1}$ AZA1 equiv.) for blue mussels (8.97 mg. $\mathrm{kg}^{-1}$ AZA1 equiv.) and pacific oysters ( $0.31 \mathrm{mg}^{\mathrm{kg}}{ }^{-1} \mathrm{AZA} 1$ equiv.). In France, high records have been observed for King scallops (Pecten maximus, 0.32 mg.kg ${ }^{-1}$ ) (Magdalena et al., 2003a) and Queen scallops (Aequipecten opercularis, 0.27 mg.kg-1 AZA1 equiv.) (Amzil et al., 2008). AZA distribution in bivalve molluscs was studied in King scallops (Magdalena et al., 2003b) and mussels (Furey et al., 2003; Hess et al., 2005; James et al., 2002). In blue mussels from Norway, toxin concentration in the digestive gland (DG) was significantly higher than in the remaining flesh (RF) (James et al., 2002). However, as the RF represents $\pm 85 \%$ of total mussel flesh it still 
has a considerable sanitary impact (Furey et al., 2003). The total AZA tissue distribution for cooked and uncooked tissues was also studied (Hess et al., 2005), the ratios between the DG and the whole flesh tissues were 5.20 and 5.89, respectively, and hence the authors concluded that the whole tissue should be analysed for official control.

Due to the large number of AZA-analogues observed in mussels (Rehmann et al., 2008), recent investigations on AZA biotransformation in mussels focussed on AZAs metabolic pathways and chemical transformations. The decarboxylation of AZA17, $-21,-19$ and -23 , i.e. carboxy-AZA analogues, into AZA3, $-4,-6$ and -9 , respectively, was demonstrated by (McCarron et al., 2009), while the formation of AZA17 was observed following immersion of mussels in sea water containing dissolved AZA1 (O'Driscoll et al., 2011). However, to our knowledge there has not been so far, any controlled study of accumulation, detoxification and biotransformation kinetics. A previous study (Salas et al., 2011) established a link between $A$. spinosum and AZAs in bivalves and pointed towards rapid biotransformation of AZA1 and -2 over a $24 \mathrm{~h}$ period of time when mussels were fed $A$. spinosum.

The present study was designed to confirm our preliminary results (Salas et al., 2011) regards the accumulation of AZAs in blue mussels (Mytilus edulis). As in the previous trial $A$. spinosum was used and a particular attention was paid to biotransformation into analogues that could represent a potential threat to human health. Furthermore, the study provided some information on accumulation and detoxification kinetics, as well as on tissues distribution and to possible effects of $A$. spinosum on mussel digestive tissues.

\section{Material and methods}

\subsection{Maintenance of bivalves}

Blue mussels (Mytilus edulis) were collected from a mussel farm in Pen Bé (French Atlantic coast) and delivered alive. Through routine official control, this area was known at that time as not affected by any known toxins. Mussels were collected in January 2011, had a mean individual dry weight of $0.35 \pm 0.1 \mathrm{~g}$ and a mean individual shell length of $47 \pm 4 \mathrm{~mm}$ (i.e. commercial size). Mussels were cleaned of barnacles on their shells and $20 \mathrm{~kg}$ were selected (size $>4 \mathrm{~cm}$ ) and divided into batches of $1 \mathrm{~kg}$. Mussels were then maintained in two $160 \mathrm{~L}$ cylindro-conical tanks for 5 days to ensure acclimatisation to laboratory conditions, i.e. re-circulated filtered seawater ( $35 \mathrm{psu}$ ) at $12.5 \pm 1^{\circ} \mathrm{C}$ with aeration. Prior to the experiment, seawater in the holding tanks was changed twice and any dead mussels were removed. During this period, mussels were not fed, thus allowing for food clearance from the digestive tract. Before starting exposure to $A$. spinosum, four $1 \mathrm{~kg}$ batches were placed into each of the 5 cylindro-conical tanks. For information on initial conditions, 30 mussels were randomly selected for wet and dry weight, ten for total flesh toxin analysis, and ten for DG and RF toxin analysis.

\subsection{Mass culture and cell count}

\subsubsection{A. spinosum}

The 3D9 strain of Azadinium spinosum was the source of AZA1 and -2 for contamination trial. This dinoflagellate was isolated during a research cruise in the North Sea near the coast of Scotland (Tillmann et al., 2009) and obtained from the Alfred Wegner Institute. The algae were produced in stirred photobioreactors $(100 \mathrm{~L})$ operated in chemostat mode at a flow rate of 0.25 day $^{-1}$. Culture medium was a K modified medium (Keller et al., 1987), without $\mathrm{NH}_{4} \mathrm{Cl}$ and with $\mathrm{Na}_{2} \mathrm{SeO}_{3}\left(10^{-8} \mathrm{M}\right)$. The following conditions were controlled in the bioreactor: $\mathrm{pH}$ was maintained at 7.9 using $\mathrm{CO}_{2}$ addition, temperature at $18^{\circ} \mathrm{C}$, Photon Flux Density at 
$200 \mu \mathrm{mol} \cdot \mathrm{m}^{-2} \cdot \mathrm{s}^{-1}$, photoperiod was $16 \mathrm{~h}$ of light and $8 \mathrm{~h}$ of dark (Jauffrais et al., 2010). A paddle was homogenizing the culture at $40 \mathrm{rpm}$. The algae were then collected into an aerated harvesting tank $(300 \mathrm{~L})$ and maintained at $18^{\circ} \mathrm{C}$ until the feeding experiment.

\subsubsection{Isochrysis aff. galbana}

Isochrysis aff. galbana (CCAP 927/14), a Prymnesiophycea, is a flagellate micro-alga widely used in aquaculture and especially in bivalve hatcheries. This alga was chosen as a nontoxic diet as it is widely used for bivalves and like $A$. spinosum is a small motile single cell alga. Nevertheless, with a size of $4-6 \mu \mathrm{m}$ it is slightly smaller than $A$. spinosum, so cell concentration of both in mixture diet were easy to quantify using a particle counter. T-Iso was grown in a bioreactor (100L) in batch culture with the same environmental conditions as for A. spinosum, but using F/2 culture medium (Guillard, 1975; Guillard and Ryther, 1962).

\subsubsection{Cell counts}

Cell concentrations (cells. $\mathrm{mL}^{-1}$ ), were determined using a particle counter (Multisizer 3 Coulter counter, Beckman) and assessed 3 times a day in the different conditions studied to control and adjust spectrofluorometric values (see below).

\subsection{Experimental design}

\subsubsection{Systems used}

The first experiment on azaspiracids accumulation and detoxification in $M$. edulis was carried out with four identical re-circulation systems. Each system was composed of an algal glass vessel (25L containing A. spinosum, T-Iso or the mixture of both) connected to a thermoregulated cylindro-conical tank (160L) with aeration (airlift system). Algal concentration in these experimental tanks was maintained by sequential addition of algae. The concentration was continuously assessed using a spectrofluorometer (Turner Design 10-AU-105) connected through a datalogger to a computer system (software: Lab View ${ }^{\Theta}$ ). When the algal concentration was below the required level, algal culture was automatically added by means of an electro-valve. Water level was maintained steady in the tank using a peristaltic pump connecting an overflow tube to a bin. Temperature and salinity were the same as during the acclimatisation period and maintained at $12.5^{\circ} \mathrm{C}$ and $35 \mathrm{psu}$.

For a second experiment on the distribution of AZAs throughout mussel organs, only the thermo-regulated cylindro-conical tank (160L) with aeration (airlift system) was used.

\subsubsection{Accumulation and detoxification experiment}

Blue mussels were used to examine the effect of $A$. spinosum on AZA accumulation, detoxification and biotransformation in bivalves, using 3 diets. Over 7 days, mussels were exposed to: (1) a constant $A$. spinosum concentration of 5000 cells. $\mathrm{mL}^{-1}$, (2) a constant $A$. spinosum concentration of 10000 cells. $\mathrm{mL}^{-1}$, (3) a mixed diet of $A$. spinosum and T-Iso, both at a concentration of 5000 cells. $\mathrm{mL}^{-1}$. Two different concentrations were assessed to verify if AZA accumulation could be dependent on $A$. spinosum concentration. Furthermore, the mixture of a toxic alga with a non-toxic alga was used to confirm that mussels are unable to selectively feed, and to see if this addition has an effect on AZA accumulation.

For detoxification, mussels of all 3 conditions were exposed to a constant concentration of TIso at 10000 cells. $\mathrm{mL}^{-1}$ for 14 days. The fourth system used was a control, where mussels were fed T-Iso diet at 10000 cells. $\mathrm{mL}^{-1}$ along the 3 weeks of this trial. Mussel total wet flesh ( 3 analysis of 10 individuals pooled) was sampled for AZAs analysis in each condition at 0 , $0.25,1,2,3,6,7,8,14,21$ days of experiment. Mussel DG and RF (3 analyses of 10 DG or 
RF pooled) were sampled for AZAs analysis in wet tissues in each condition after 3 and 7 days contamination and after 1 week (day 14) and 2 weeks detoxification (day 21).

(Notice: the hypothesis was made that AZA concentration in mussel of similar size followed a normal distribution under the same experimental condition. Thus, a large number of mussels were sampled and subsequently pooled to reduce analytical work.)

\subsubsection{Distribution in blue mussel}

To assess AZAs distribution throughout tissues, mussels $(4 \mathrm{~kg})$ were exposed for $24 \mathrm{~h}$ to an initial $A$. spinosum concentration of 60000 cells. $\mathrm{mL}^{-1}$. Mussels (30 individuals) were then carefully dissected and rinsed with Milli-Q water to avoid possible contamination with remaining $A$. spinosum cells. The following tissues were pooled for analysis: digestive gland (DG), gills, mantle margins (MM), mantle (M), labial palp (LP), posterior adductor muscle (PAM), foot, and remaining flesh (RF).

\subsection{Extraction procedures}

\subsubsection{Reagents}

Acetone and methanol $(\mathrm{MeOH})$ were obtained as HPLC grade solvents from JT Baker. Milli-Q water for the HPLC mobile phase was supplied by a Milli-Q integral 3 system (Millipore). Formic acid (Puriss quality) and ammonium formate (Purity for MS) were from Sigma Aldrich. AZA1 calibrants for LC-MS/MS analysis were dilutions of certified AZA1 solution obtained from the National Research Council, Canada.

\subsubsection{Azadinium spinosum}

Triplicate samples of $A$. spinosum were taken after each addition of algae in the $25 \mathrm{~L}$ algal tanks ( 4 times over the 7 days of the contamination period) at day $0,1,3$ and 5 respectively. The analytical procedure had previously been optimised (Jauffrais et al., in press). Briefly, aliquots $(10 \mathrm{~mL})$ of $A$. spinosum cultures were collected and centrifuged $(2500 \mathrm{~g}, 20 \mathrm{~min}$, $4^{\circ} \mathrm{C}$ ) in $15 \mathrm{~mL}$ centrifuge tubes. The supernatant was discarded and the pellet was resuspended with $0.5 \mathrm{~mL}$ of acetone $/ \mathrm{H}_{2} \mathrm{O}(9 / 1, v / \mathrm{v})$, transferred to an Eppendorf tube $(1.5 \mathrm{~mL})$ and bath sonicated (10 min). After sonication, the aliquot was centrifuged (15 $000 \mathrm{~g}, 10 \mathrm{~min}$, $4^{\circ} \mathrm{C}$ ). The supernatant was transferred into a $5 \mathrm{~mL}$ glass tube and gently evaporated under nitrogen on a heating block at $35^{\circ} \mathrm{C}$. The pellet was re-suspended in $0.5 \mathrm{~mL}$ of acetone $/ \mathrm{H}_{2} \mathrm{O}$ $(9 / 1, v / v)$, homogenised and centrifuged again. The supernatant was transferred again into the same $5 \mathrm{~mL}$ glass tube used before and gently evaporated. This process was repeated three times in total. After evaporation of supernatants, the residue was reconstituted in $1 \mathrm{~mL}$ methanol/ $\mathrm{H}_{2} \mathrm{O}(9 / 1, v / v)$. Subsequently, an aliquot was filtered with NANOSEP MF centrifugal filter $0.2 \mu \mathrm{m}$ (PALL) $\left(15000 \mathrm{~g}, 3 \mathrm{~min}, 4^{\circ} \mathrm{C}\right)$, and transferred into a HPLC vial with $250 \mu \mathrm{L}$ insert for analysis.

\subsubsection{Mussel tissues}

Mussel tissues were collected at the different time points of the experiments. Tissues were carefully removed using a dissection scalpel, drained for $5 \mathrm{~min}$ and weighed to measure wet weight. They were then placed into labelled $50 \mathrm{~mL}$ centrifuge tubes and stored until extraction at $-20^{\circ} \mathrm{C}$. Prior to extraction, the tissues were thawed and homogenized using a high-speed homogeniser (Polytron PT1200c) at $15000 \mathrm{rpm}$ for $5 \mathrm{~min}$. Aliquots $(2 \mathrm{~g} \pm 0.2 \mathrm{~g})$ were taken in triplicate, weighed on a 3-place balance (Sartorius Cubis MSA) and placed into labelled $50 \mathrm{~mL}$ centrifuge vials. Methanol $(9 \mathrm{~mL})$ was added to each vial and samples were extracted using a high-speed homogeniser (Polytron PT1300D) at $15000 \mathrm{rpm}$ for $2 \mathrm{~min}$. 
Samples were then centrifuged at $4000 \mathrm{~g}$ for $5 \mathrm{~min}$ at $4^{\circ} \mathrm{C}$, and the supernatant was transferred into $20 \mathrm{~mL}$ volumetric flasks. Another $9 \mathrm{~mL}$ of methanol was added to the remaining pellet and homogenized again. Centrifugation was repeated at above parameters, and supernatants were transferred into the same $20 \mathrm{~mL}$ volumetric flasks. Volumetric flasks were then made up to the mark using methanol, homogenised and aliquots ( $400 \mu \mathrm{L})$ were spin-filtered through $0.22 \mu \mathrm{m}$ Eppendorf in-vial filters $\left(15000 \mathrm{~g}, 3 \mathrm{~min}, 4^{\circ} \mathrm{C}\right.$ ), and filtrates were subsequently transferred into HPLC vials with $250 \mu \mathrm{L}$ insert to be analysed using LC-MS/MS (Villar-Gonzalez et al., 2011).

\subsection{LC-MS/MS analysis}

The samples were analysed by LC-MS/MS to quantify AZAs using a HPLC (model UFLCxr, Shimadzu) coupled to a triple quadrupole mass spectrometer (API 4000Qtrap, Applied Biosystems). Separation was performed on a silica-based reversed phase column (injection volume $5 \mu \mathrm{L})$, MOS-Hyperclone C $8(50 \times 2 \mathrm{~mm}, 3 \mu \mathrm{m}$ particle size; Phenomenex). The mobile phases $A$ and B were $100 \%$ water and acetonitrile/water $(95 / 5, v / v)$ respectively both containing $2 \mathrm{mM}$ ammonium formate and $50 \mathrm{mM}$ formic acid. The column was used with a gradient elution of $200 \mu \mathrm{L} \cdot \mathrm{min}^{-1}$ at $20^{\circ} \mathrm{C}$. Gradient elution for AZA determination started with $70 \% \mathrm{~B}$ rising to $100 \% \mathrm{~B}$ for $2 \mathrm{~min}$, held for $7 \mathrm{~min}$, decreasing to $70 \% \mathrm{~B}$ over $0.5 \mathrm{~min}$, and held for $5 \mathrm{~min}$ until the next run. The mass spectrometer was operated in multiple reaction monitoring (MRM) in positive ion mode. Based on a previous study (Rehmann et al., 2008), the transitions presented in table 1 were used for quantification. The declustering potential was $116 \mathrm{~V}$, the entrance potential $10 \mathrm{~V}$, the cell exit potential 12 and $16 \mathrm{~V}$, and the collision cell were 41 and $69 \mathrm{~V}$ for fragmentation 1 and 2 respectively. The electrospray ionisation interface (ESI) was operated using the following parameters: curtain gas: $30 \mathrm{AU}$ (Arbitrary Unit); temperature: $450^{\circ} \mathrm{C}$; gas 1: $50 \mathrm{AU}$; gas 2: $50 \mathrm{AU}$; CAD gas: medium; ion spray voltage: 5500V. Quantifications were carried out using external calibration against AZA1, with Analyst 1.5 software (Applied Biosystems), assuming that all analogues have the same response factor as AZA1.

Toxic Equivalent Factors (TEFs) were also applied to estimate the true toxic potential of mussel samples during the experiment. AZA1 TEFs applied were equal to 1.8 and 1.4 for AZA2 and -3 , respectively (Ofuji et al., 1999) and a provisional TEF of 1 was used for crude estimation of the toxicity represented by AZA6. Consequently, a TEF of 1.4 and 1 were applied to AZA17 and -19 , respectively, as AZA17 and -19 transform into -3 and -6 after cooking (McCarron et al., 2009).

\subsection{Histology}

Mussels (five individuals) were sampled for each condition at days $0,2,7$ and 21 , to observe possible changes in digestive gland tubules and recovery of digestive tissues over the feeding experiment (toxic and non-toxic diets were compared). The mussels tissues were fixed in Davidson's fixative (Shaw and Battle, 1957) for $48 \mathrm{~h}$ and conserved in $70 \%$ ethanol until inclusion. Sections of mussel tissues were then dehydrated using ClaRAL (tetrachloroethylene) and ethanol solutions. A cross section $(5 \mu \mathrm{m})$ was then cut from each mussel tissue sampled, including the digestive gland, gills, mantle and gonad. Afterward, staining was carried out using haematoxylin-eosin solutions. Slides were examined using light microscopy (Leica DM2000). The thickness of the digestive gland tubules was assessed to determine their state (Medhioub, 2011); measurements were carried out on each individual at three distinct locations on the histological plate. In each location, the thickness of 10 digestive gland tubules was measured using Leica Application Suite 2.8.1 software. 


\subsection{Statistical analysis}

All data are expressed as mean \pm standard deviation. Statistical analyses consisted of oneway analysis of variance (ANOVA) followed by a Fisher's least significant difference (LSD) procedure. Differences were considered significant at $p<0.05$. Statistical analyses were carried out using Statgraphics Centurion XV.I (STATPOINT TECHNOLOGIES, INC.). Before each ANOVA analysis normality and equality of variance were tested.

Detoxification was modelled as one or two compartment kinetics, for comparison with previously reported detoxification of lipophilic toxins in bivalve molluscs. A one compartment model supposed a similar detoxification kinetic of the mussel tissues, whereas a two compartment model is explained by the fast excretion of the toxin non retained by the digestive tract (compartment 1) and by the slow detoxification of the toxins bound to the mussel tissues (compartment 2) (Blanco et al., 1997; Bricelj and Shumway, 1998; Lassus et al., 2007).

To improve the strength of the detoxification model, and as all treatment groups were given the same diet for detoxification, the values for each condition were standardised using the average of the toxin concentration at the start of detoxification. Subsequently, standardised values were averaged, and detoxification kinetics were assessed according to the following models using MATLAB version 7.4.0:

$$
\begin{gathered}
C_{t}=C_{0} \times \exp (-k \times t) \\
C_{t}=C_{a} \times \exp \left(-k_{1} \times t\right)+\left(1-C_{a}\right) \times \exp \left(-k_{2} \times t\right)
\end{gathered}
$$

(equation 1)

(equation 2)

Where $C_{0}$ is the initial toxin concentration, $C_{a}$ the toxin loss by the first compartment, $k$ the mean detoxification rate $\left(\mathrm{day}^{-1}\right)$ of the one compartment model, $k_{1}$ and $k_{2}$ are the detoxification rate $\left(\right.$ day $\left.^{-1}\right)$ of the first and second compartment respectively and $t$ the time in days. Subsequently, to calculate the half-life $T_{1 / 2}$ i.e. the theoretical time in days to reach a $50 \%$ reduction in toxin concentration, the equation below (deduced from equation 1) was used:

$$
\mathrm{T}_{1 / 2}=\ln (1 / 2) \mathrm{k}^{-1}
$$

(equation 3)

For this first approach to detoxification kinetics, and as no $A$. spinosum were consumed by mussels during the last day of contamination (experimental observation), detoxification was considered to have started on day 6 . We also made the hypothesis that diets used during the contamination period did not affect detoxification kinetics.

\section{Results}

\subsection{AZA profile of $A$. spinosum culture}

The cultured $A$. spinosum strain 3D9 produced AZA1 and -2, with AZA1 as the predominant azaspiracids with a proportion of $74.6 \%\left(43 \pm 6 \mathrm{fg}^{-\mathrm{cell}^{-1}}\right)$ of the total AZAs content $\left(59 \pm 6\right.$ fg.cell $\left.^{-1}\right)$. Consequently, AZA2 proportion was $25.4 \%\left(15 \pm 6\right.$ fg.cell $\left.^{-1}\right)$.

\section{2. $A Z A$ accumulation and detoxification}

Toxin content of mussels fed with all three toxic diets followed the same pattern over the first days of contamination. A rapid contamination of $M$. edulis with azaspiracids was observed; after only $6 \mathrm{~h}$ of contamination, all toxin concentrations were above the regulatory limit in bivalve molluscs (160 $\mu \mathrm{g} \cdot \mathrm{kg}^{-1}$ AZA1 equiv., figure 1). Further accumulation appeared much 
slower until day three, where AZA total content stabilised for diet 2 at $\pm 400 \mu \mathrm{g} \cdot \mathrm{kg}^{-1}$ until the end of the contamination period (day 7 ) with $A$. spinosum. For diets 1 and 3 AZA toxin contents reached a maximum of approximately $600 \mu \mathrm{g} \cdot \mathrm{kg}^{-1}$ after 6 days of contamination. For those two conditions, a sharp decrease was observed from day 6 to 8 , in coherence with experimental observations between day 6 and 7 (where no or only low amounts of $A$. spinosum were consumed) and the beginning of the detoxification period (day 7 ).

From day 7 to the end of the feeding trials, animals of all treatments were then fed with the non-toxic alga T-Iso. Detoxification appeared to be a biphasic process (figure 2, tables 2-3). Detoxification rates $\left(k_{1}, k_{2}\right.$ and $\left.k\right)$ for total AZAs, AZA1 and -2 and AZA metabolites, presented in figure 2 and tables 2-3 appeared to differ from each other. In particular, the detoxification rate of AZAs originating from biotransformation of AZA1 and -2 in mussels was lower than the one of the AZAs biosynthesised by A. spinosum (AZA1 and -2, figure $2 \mathrm{~b}$ and tables 2 and 3 ). Overall, AZA1 and -2 were eliminated more rapidly, as they were both transformed into other analogues (figure 2b, 3 and 4 ) and excreted. Additionally, AZA1 and -2 may be excreted prior to any assimilation (absorption or protein binding). Nonetheless, after two weeks of detoxification the total AZA content was still greater than $160 \mu \mathrm{g}^{\mathrm{kg}}{ }^{-1} \mathrm{AZA} 1$ TEQ (toxic equivalents: concentrations weighted by their TEF) in all three diets studied. Detoxification kinetics appeared to be comparable between the sum of AZA1 + its metabolites and the sum of AZA2 + its metabolites (figure 2c).

\subsection{AZA biotransformation during accumulation and detoxification}

Biotransformation of AZA1 and -2 was a fast process. After $6 \mathrm{~h}$ of contamination, $25 \%$ of the AZA proportion in total mussel flesh was metabolites in all 3 conditions tested, and this proportion increased up to $50 \%$ after 1 and 2 days of contamination. Furthermore, the metabolite proportion tended to slowly increase until the end of the contamination and detoxification period to represent $60-65 \%$ of the total in all 3 conditions tested (figure 3 ). Interestingly, when DG were separated from RF the global pattern differed between the two fractions as shown in figure 3 . From the third day of contamination to the end of the detoxification period the ratio between AZA1 and -2 and their metabolites was stable (around $50 \%$ ) in the DG, whereas in the RF the percentage of metabolites increased from day 3 to the end of the detoxification period from 50 to $70 \%$.

The temporal variation in the proportion of the different AZA toxins in mussel tissues is presented in table 4 for diet 1 (the temporal variation with diet 2 and 3 followed the same kinetics of AZA biotransformation). In less than six hours, biotransformation of AZA1 and -2 occurred. In order of decreasing importance, AZA 17, -19, 7-8, 6, 11-12 and -3 were found, with a proportion of AZA17 equal to AZA2. After $24 \mathrm{~h}$ of contamination AZA5 was found in addition to the previous AZAs; the proportion of AZA17 and -19 increased twofold, with a proportion of AZA17 equal to AZA1. From then until the end of the contamination period the proportion between metabolites and primary AZAs stabilised. It is important to notice the increase in the number of metabolites over time, AZA4, -10 and 21 after 2 days, followed by AZA23 at day 3 and AZA9 at day 6 . After six days no new AZA analogues were detected. Over the detoxification period, bioconversion processes were still occurring, with an increase in the proportion of AZA4-6 and AZA21-23. Nonetheless, during this feeding trial AZA17 appeared to be the major metabolite, with proportions similar to AZA1.

The proportion of AZA toxins at the end of the period of contamination and detoxification in DG and RF is presented in table 5. As before-mentioned the proportion of metabolites was different in the two types of tissues. All AZA analogues detected during this feeding trial were found in the DG, whereas AZA9-12 were not found in the RF. A larger proportion of AZA17 was present in the RF than in the DG. In the RF AZA17 became the dominating AZA analogue, with its content increasing from 1.5 to 2 times the AZA1 concentration; whereas the other analogues found in the RF remained at low levels. 


\subsection{AZA distribution in blue mussels}

A separate batch of mussels was contaminated for this evaluation. Contamination was carried out over $24 \mathrm{~h}$ using $A$. spinosum at an initial concentration of 60000 cells. $\mathrm{mL}^{-1}$. The total flesh toxicity was $517 \pm 18 \mu \mathrm{g} \cdot \mathrm{kg}^{-1}$ (table 6). The proportion of AZAs is presented in figure 5 , where $73 \%$ of the AZAs were found in the DG, $11 \%$ in the RF and $8 \%$ in the gills. The other tissues showed minor amounts of toxins with values below $3 \%$ of the total toxin accumulated (figure 5). AZA concentrations in $M$. edulis tissues are presented in table 6 and the AZA profile of each dissected tissue in figure 5. AZA1-6, -8, 11-12, $-17,-19,-21$ and -23 were found in the DG. In decreasing order of concentration, the four major AZAs were AZA1, $-17,-2,-19$. These four analogues were found in all tissues, however only AZA1 and -17 were significant in tissues with minor amount of toxins (MM, LP, M, PAM, Foot).

\subsection{Assessment of $A$. spinosum effect on mussels}

\subsubsection{Mortality}

Mortality rates of mussels fed the different diets were low as shown in table 7 . However, mortality rates were higher in the diets based on $A$. spinosum than in the control condition with T-Iso that showed $2 \%$ mortality during the whole feeding trials.

\subsubsection{Histology}

To assess a possible effect of $A$. spinosum on the digestive tissues of mussels, digestive gland tubules were examined at the beginning of the feeding trial, after 2 and 7 days of contamination and at the end of the detoxification period. A. spinosum had a negative effect on the thickness of digestive gland tubules when comparing the different diets based on $A$. spinosum after 2 or 7 days of contamination with the control or the initial condition of the digestive gland tubules (figure 6). After two weeks of detoxification a recovery was observed for all survivors examined as no differences between toxic and non-toxic diets were noted.

\section{Discussion}

The $A$. spinosum toxin concentration per cell from the harvesting tank $\left(59 \pm 6\right.$ fg.cell $\left.^{-1}\right)$ was within the large range already observed for this species, from 5 to 40 fg.cell $^{-1}$ in batch culture (Salas et al., 2011; Tillmann et al., 2009) and up to 100 fg.cell $^{-1}$ in chemostat bioreactors (Jauffrais et al., 2010; Jauffrais et al., 2011) and had the usual toxin profile with AZA1 as the major AZA.

After $6 \mathrm{~h}$, the total AZA content reached twice the regulatory limit in all three different diets studied. Therefore, the AZA accumulation in mussels should be considered as a very fast process, at least at the concentrations tested here $\left(5-10 \times 10^{3} \mathrm{ml}^{-1}\right)$. Comparison of these results to the field situation, however, is hampered to the fact that abundance data of $A$. spinosum in European field samples are completely lacking. Nevertheless, the concentration corresponds to the reports on $A$. spinosum densities in coastal Argentinian waters, where a maximum concentration of $9 \times 10^{6}$ cells. $L^{-1}$ in 1990 and values ranging from 0.5 to $3 \times 10^{6}$ cells. $L^{-1}$ in 1991 were observed (Akselman and Negri, 2010). A rapid accumulation of AZAs in case of $A$. spinosum blooms underlines difficulties in monitoring toxins for sanitary purposes and the necessity to predict when such an event might occur. Over 7 days, toxin content in mussels increased to reach a maximum concentration of around $600 \mu \mathrm{g}^{-1} \mathrm{gg}^{-1}$ in diet 1 and 3 both containing 5000 cells. $\mathrm{mL}^{-1}$ of $A$. spinosum, whereas in diet $2\left(10000\right.$ cells. $\mathrm{mL}^{-1}$ of $A$. spinosum) the toxin content reached a maximum concentration of $\pm 400 \mu \mathrm{g}_{\mathrm{kg}}{ }^{-1}$. The addition of a non-toxic species to $A$. spinosum neither significantly affect $A Z A$ accumulation. Also, the higher $A$. spinosum concentration did not result in increased AZA accumulation but 
rather seemed to reduce AZA accumulation. However, these findings should not be overinterpreted as such trials should be repeated to increase statistical significance.

These toxin contents in blue mussels were within the range of what is frequently found in the Irish monitoring program (Salas et al., 2011). However, mussels did not build up very high levels over the duration of the accumulation phase (7 days). This result suggests that, in natural conditions, exposure of mussels to Azadinium may be either longer than 7 days or involve more complex trophic mechanisms such as biomagnification via other planktonic organisms. Furthermore, the study shows the limits of preparative-scale production of AZAmetabolites through in vivo exposure of mussels. Still, the procedure may be useful for production of in-house metabolite reference materials as suggested by (Hess et al., 2007), and demonstrated for paralytic shellfish toxins (Higman and Turner, 2010).

Detoxification of mussels fed with T-/so was carried out over two weeks. Supplying non-toxic diet has been previously proposed by several authors to enhance detoxification after exposure of bivalves to saxitoxin (STX) or lipophilic toxins (okadaic acid, gymnodimine) (Lassus et al., 2005; Lassus et al., 2000; Marcaillou et al., 2010; Medhioub et al., 2010). The detoxification kinetic was slow, even if toxin elimination from mussels followed a biphasic kinetic, with a rapid first and a slow second phase (figure 2 and table 3 ); in all cases mussels were above the regulatory limit after two weeks of detoxification when all AZAs found were taken into account and not only the three regulated AZAs. Biphasic kinetics of detoxification have already been described for OA-group toxins, gymnodimines and the paralytic shellfish poisoning (PSP) group (Blanco et al., 1997; Bricelj and Shumway, 1998; Lassus et al., 2007; Marcaillou et al., 2010; Medhioub et al., 2010). Mean detoxification rates were in the same range as those previously reported for okadaic acid $(O A)$ and its derivative $(-0.048$ for total OA) (Marcaillou et al., 2010). Detoxification rates for total AZAs, algal AZAs (AZA1-2) and AZA metabolites differed because AZA1 and -2 are transformed into other analogues during detoxification. Thus, models only taking into account regulated AZAs (AZA1, -2 and -3 ), would overestimate the real detoxification rate (figure 2). Consequently, detoxification models should take into account all AZAs present or at least the major algal and shellfish metabolites (AZA1 and -2, AZA17 and -19). The slow, gradual detoxification (second phase, figure 2 and table 3 ) has been explained as a possible result of AZA movements from the digestive gland to the other tissues where elimination would be slower (James et al., 2004; James et al., 2002). However, this hypothesis was a result of in situ observations where various other possibilities could interfere, including reduction of the mussel metabolism during winter time (Twiner et al., 2008), or possible presence of dissolved AZAs or A. spinosum, even if natural conditions seem unfavourable. Interestingly, (Nzoughet et al., 2008) found that AZAs were weakly bound to a protein with a molecular weight of $45 \mathrm{kDa}$ in DG, a fact that may explain the slow AZA detoxification from mussels (Twiner et al., 2008).

The detoxification rates reported here are to our knowledge the only information on detoxification kinetics after exposure to $A$. spinosum and represent a first approach with this toxin; however, the low number of points analysed along the detoxification period and the large confidence level observed (figure 2a) demonstrates the need of further experiments.

It is known that the bioconversion of algal toxins by bivalves may influence overall toxicity (Twiner et al., 2008). Therefore, it is important to understand both toxin profiles and bioconversion kinetics. Biotransformation of AZA1 and -2 in mussels was found to be a fast process. These results confirmed the first feeding experiment carried out during $24 \mathrm{~h}$ with the Irish strain (SM2) of $A$. spinosum (Salas et al., 2011), where a rapid bioconversion of AZA1 and -2 into AZA17, -19 and -3 was found, with AZA17 as the major bioconversion product after $24 \mathrm{~h}$ of experiment. In addition to the study by Salas et al., 2011, the present study revealed that all AZA analogues (apart from AZA13-16) already observed in naturally contaminated mussels were found in mussel tissues exposed to $A$. spinosum. However, none of the theoretical AZAs (Rehmann et al., 2008) were observed. This suggests that 
direct accumulation of $A$. spinosum by mussels may be sufficient to explain the observed toxin profiles.

Bioconversion of azaspiracids is a recent subject of study. Formation of AZA3, $-4,-6$ and -9 via decarboxylation of AZA17, $-21,-19$ and -23 respectively has been shown (McCarron et al., 2009), with some additional experimental evidence provided by O'Driscoll et al. (2011). In the present study, the order of appearance of the bioconversion products seemed to link AZA3, $-4,-6$ and -9 with their carboxylated analogues and hence confirms previous results obtained by McCarron et al. (2009), as AZA17 and -19 appear first and constitute already more than $20 \%$ of total AZAs after $6 \mathrm{~h}$. Additionally, the ratio of AZA17/AZA19 is similar to that of AZA1/AZA2. Therefore, it appears plausible to assume that there is a direct transformation of AZA1 into AZA17 and of AZA2 into AZA19. Decarboxylation of AZA17 into -3 and of AZA19 into -6 is much slower, which is consistent with the heat-accelerated character of this transformation already reported by McCarron et al. (2009). Furthermore, AZA3 and -6 proportions remain relatively constant after their appearance, suggesting that their transformation into AZA4 and -5 as well as AZA9 and -10 , respectively, is of similar speed as the decarboxylation reaction in C22. Simultaneous hydroxylation of AZAs in C3 or C23 into other analogues is not excluded, as the stability of AZA3 proportion suggests that it could be relatively rapidly hydroxylated into AZA5 and more slowly into AZA4. This phenomenon is also noted through the earlier appearance of AZA5, somewhat convoluted by the higher AZA4 concentration at the end of the experiment which can be understood through the dual route towards AZA4 via AZA3 and -21 (see below). This hypothesis is supported by the biotransformation kinetics: hydroxylated analogues in C3 (AZA7 and -11) required more time ( $\geq 48 \mathrm{~h}$ ) to be formed than hydroxylated analogues in C23 (6-24 h, AZA5, $-8,-10)$ (note: despite a lack in chromatographic separation in the analysis, using specific transitions in MS, it was established that AZA7 and -11 appeared after $48 \mathrm{~h}$ ). The formation of the carboxy-hydroxylated analogues (AZA21 and -23) also required more time ( $\geq 48 \mathrm{~h}$ ) than the formation of carboxylated analogues (AZA17 and -19) which suggests that hydroxylation of $\mathrm{C} 3$ or $\mathrm{C} 23$ is a slower process than oxidation of the methyl-group at C22 as AZA4 and -5 were not yet present after $6 \mathrm{~h}$. At the end of the study AZA4 was more concentrated than AZA5, which is consistent with the dual route leading to this metabolite. Also, overall, the biotransformation of AZA2 and all its analogues appears somewhat slower than that of AZA1 metabolites. This can be seen in the slightly higher ratio of AZA2/AZA19 compared to AZA1/AZA17 throughout the study. The analogues hydroxylated in both $\mathrm{C} 3$ and C23 were not detected over the three weeks of experiment and so presumably require much more time to be formed (consistent with the fact that there is two or more slow transformations involved). Following all these observations possible biotransformation pathways of AZA1 and -2 were proposed (figure 4).

As a consequence, the fast AZA oxidation process in mussels has to be considered by regulators, as AZA17 and -19 are major metabolites in raw mussels, and are obviously not readily converted into AZA3 or -6 over time. Therefore, research should focus on AZA17 and -19 production and isolation to determine their potency to human health. The different monitoring programs currently underestimate the total amount of AZA present in mussels. As mussels are typically consumed after cooking, AZA17 and -19 are transformed into AZA3 and -6 (AZA3 already considered toxic and regulated) prior to consumption (Table 4). Thus, AZA17 and -19 should be accounted for, either directly or through heat-treatment of samples prior to analysis.

Regarding toxin distribution across mussel organs, accumulation of AZA differed between tissues in mussels, as was found with other known toxins accumulating in bivalve molluscs (DSP, ASP, PSP), where toxins were mainly found in digestive gland (Blanco et al., 2002; Blanco et al., 2007; Bricelj and Shumway, 1998; Campbell et al., 2001; Chen and Chou, 2001; Choi et al., 2003; Lassus et al., 2007). In this study, $73 \%$ of the AZAs were found in the digestive gland, $11 \%$ in the remaining flesh, $8 \%$ in the gills and negligible amounts of 
toxins in other tissues. This distribution of AZAs has already been observed in scallops and mussels naturally contaminated with AZAs (Hess et al., 2005; Magdalena et al., 2003b; Salas et al., 2011). Most AZA analogues were found in the DG at the highest concentration, it is thus supposed that biotransformation was most active in the DG. The toxin concentrations observed in the non-digestive gland tissues may result from transfer between organs or may originate from re-adsorption of excreted metabolites as the system was recirculated.

Concerning the effect of $A$. spinosum on digestive gland tubule thickness, the decrease in thickness was observed for all toxic diets compared to the control diet over the contamination period. However, a recovery was observed at the end of the detoxification period. This phenomenon on bivalve physiology was previously observed with other toxins (Galimany et al., 2008; Medhioub, 2011; Pearce et al., 2005), and shows A. spinosum as a possible physiological factor of stress to shellfish.

\section{Conclusions}

The study confirmed the direct transfer of AZA toxins from $A$. spinosum to mussels, and the fast biotransformation of AZA1 and -2 into other analogues, especially into AZA17 and -19. It also showed that blue mussels can accumulate AZAs to levels above the regulatory limit in less than $6 \mathrm{~h}$ and up to $0.6 \mathrm{mg} / \mathrm{kg}^{-1}$ within a week. Detoxification kinetic was slow $\left(T_{1 / 2}\right.$ approximately 11 days); with detoxification rates in the same order as other lipophilic toxins.

The study underlines that AZA17 and -19 were present at significant levels already after $6 \mathrm{~h}$ and until the end of the study. Therefore, these analogues need to be considered as major metabolites which affect human health, either by themself or through thermal conversion to AZA3 and -6 . It is thus necessary to revise the regulation on AZAs, currently based on the analysis of raw bivalves by LC-MS/MS.

\section{Acknowledgment}

This study was carried out under the Sea Change strategy with the support of the Marine Institute and the Marine Research Sub-Programme of the National Development Plan 20072013, co-financed by the European Regional Development Fund (ASTOX2). Further funding was obtained through Ifremer from the French Ministry of Education, Research and Technology through Programme 187 of the National Finance Law. The authors would like to thank all the members of the laboratory EMP/PHYC at the Atlantic Centre of Ifremer for their help and technical advice during this study and especially Drs. Patrick Lassus and Régis Baron for the constructive discussions and valuable comments.

\section{References}

Akselman, R., Negri, R.M., 2010. Azadinium spinosum Elbrächter et Tillmann (Dinophyceae) is present and also caused blooms at the southwestern atlantic. Abstract book of the 14th International conference on harmful algae, Hersonissos, 132.

Alvarez, G., Uribe, E., Avalos, P., Marino, C., Blanco, J., 2010. First identification of azaspiracid and spirolides in Mesodesma donacium and Mulinia edulis from Northern Chile. Toxicon 55, 638-641. 
Amzil, Z., Sibat, M., Royer, F., Savar, V., 2008. First report on azaspiracid and yessotoxin groups detection in French shellfish. Toxicon 52, 39-48.

Anonymous, 2005. Commission Regulation (EC) No 2074/2005 of 5 December 2005 laying down implementing measures for certain products under Regulation (EC) No 853/2004 of the European Parliament and of the Council and for the organisation of official controls under Regulation (EC) No 854/2004 of the European Parliament and of the Council and Regulation (EC) No 882/2004 of the European Parliament and of the Council, derogating from Regulation (EC) No 852/2004 of the European Parliament and of the Council and amending Regulations (EC) No 853/2004 and (EC) No 854/2004 Official Journal L 338, 22/12/2005, pp. 27-59.

Blanco, J., Acosta, C.P., de la Puente, M.B., Salgado, C., 2002. Depuration and anatomical distribution of the amnesic shellfish poisoning (ASP) toxin domoic acid in the King scallop Pecten maximus. Aquat. Toxicol. 60, 111-121.

Blanco, J., Marino, C., Martin, H., Acosta, C.P., 2007. Anatomical distribution of diarrhetic shellfish poisoning (DSP) toxins in the mussel Mytilus galloprovincialis. Toxicon 50, 10111018.

Blanco, J., Morono, A., Franco, J., Reyero, M.I., 1997. PSP detoxification kinetics in the mussel Mytilus galloprovincialis. One- and two-compartment models and the effect of some environmental variables. Mar. Ecol. Prog. Ser. 158, 165-175.

Bricelj, V., Shumway, S., 1998. Paralytic shellfish toxins in bivalve molluscs: Occurrence, transfer kinetics, and biotransformation. Reviews in Fisheries Science 6, 315-383.

Campbell, D.A., Kelly, M.S., Busman, M., Bolch, C.J., Wiggins, E., Moeller, P.D.R., Morton, S.L., Hess, P., Shumway, S.E., 2001. Amnesic shellfish poisoning in the King scallop, Pecten maximus, from the west coast of Scotland. Journal of Shellfish Research 20, 75-84.

Chen, C.Y., Chou, H.N., 2001. Accumulation and depuration of paralytic shellfish poisoning toxins by purple clam Hiatula rostrata Lighttoot. Toxicon 39, 1029-1034.

Choi, M.C., Hsieh, D.P.H., Lam, P.K.S., Wang, W.X., 2003. Field depuration and biotransformation of paralytic shellfish toxins in scallop Chlamys nobilis and green-lipped mussel Perna viridis. Mar. Biol. 143, 927-934.

Diaz Sierra, M., Furey, A., Hamilton, B., Lehane, M., James, K.J., 2003. Elucidation of the fragmentation pathways of azaspiracids, using electrospray ionisation, hydrogen/deuterium exchange, and multiple-stage mass spectrometry. J. Mass. Spectrom. 38, 1178-1186.

Furey, A., Moroney, C., Magdalena, A.B., Saez, M.J.F., Lehane, M., James, K.J., 2003. Geographical, temporal, and species variation of the polyether toxins, azaspiracids, in shellfish. Envir. Sci. Technol. 37, 3078-3084.

Furey, A., O'Doherty, S., O'Callaghan, K., Lehane, M., James, K.J., 2010. Azaspiracid poisoning (AZP) toxins in shellfish: Toxicological and health considerations. Toxicon.

Galimany, E., Sunila, I., Hegaret, H., Ramon, M., Wikfors, G.H., 2008. Experimental exposure of the blue mussel (Mytilus edulis, L.) to the toxic dinoflagellate Alexandrium fundyense: Histopathology, immune responses, and recovery. Harmful Algae 7, 702-711.

Guillard, R.R.L., 1975. Culture of phytoplankton for feeding marine invertebrates, in: W.L., S., M.H, C. (Eds.), Culture of Marine Invertebrate Animals. Plenum Press, New York, USA, pp. pp 26-60. 
Guillard, R.R.L., Ryther, J.H., 1962. Studies of marine planktonic diatoms. I. Cyclotella nana Hustedt and Detonula confervacea Cleve. Can. J. Microbiol. 8, 229-239.

Hernandez-Becerril, D.U., Escobae-Morales, S., Morreno-Gutiérez, S.P., Baron-Campis, S.A., 2010. Two new records of potentially toxic phytoplankton species from the Mexican Pacific. Abstract book of the 14th International conference on harmful algae, Hersonissos, 137.

Hess, P., McCarron, P., Quilliam, M.A., 2007. Fit-for-purpose shellfish reference materials for internal and external quality control in the analysis of phycotoxins. Anal. Bioanal. Chem. 387, 2463-2474.

Hess, P., Nguyen, L., Aasen, J., Keogh, M., Kilcoyne, J., McCarron, P., Aune, T., 2005. Tissue distribution, effects of cooking and parameters affecting the extraction of azaspiracids from mussels, Mytilus edulis, prior to analysis by liquid chromatography coupled to mass spectrometry. Toxicon $46,62-71$.

Higman, W.A., Turner, A., 2010. A feasibility study into the provision of Paralytic Shellfish Toxins laboratory reference materials by mass culture of Alexandrium and shellfish feeding experiments. Toxicon 56, 497-501.

James, K.J., Fidalgo Saez, M.J., Furey, A., Lehane, M., 2004. Azaspiracid poisoning, the food borne illness associated with shellfish consumption. Food Addit. Contam. 21, 879-892.

James, K.J., Furey, A., Lehane, M., Ramstad, H., Aune, T., Hovgaard, P., Morris, S., Higman, W., Satake, M., Yasumoto, T., 2002. First evidence of an extensive northern European distribution of azaspiracid poisoning (AZP) toxins in shellfish. Toxicon 40, 909-915.

James, K.J., Sierra, M.D., Lehane, M., Magdalena, A.B., Furey, A., 2003. Detection of five new hydroxyl analogues of azaspiracids in shellfish using multiple tandem mass spectrometry. Toxicon 41, 277-283.

Jauffrais, T., Séchet, V., Herrenknecht, C., Tillmann, U., Krock, B., Amzil, Z., Hess, P., 2010. Growth and toxin production of Azadinium spinosum in batch and continuous culture. Abstract book of 14th International conference on harmful algae, Hersonissos, 39.

Jauffrais, T., Séchet, V., Truquet, P., Herrenknecht, C., Amzil, Z., Hess, P., 2011. Effect of flow rate on Azadinium spinosum and azaspiracid productivities in medium scale chemostats in series for azaspiracid-1 and -2 harvest. Abstract book of the 8th International Conference on Molluscan Shellfish safety, Charlottetown, 127.

Jauffrais, T., Herrenknecht, C., Séchet, V., Sibat, M., Tillmann U., Krock B., Kilcoyne J., Miles C. O., McCarron P., Amzil Z., Hess P., 2012. Quantitative analysis of azaspiracids in Azadinium spinosum cultures. Anal Bioanal Chem. DOI: 10.1007/s00216-012-5849-2.

Keller, M.D., Selvin, R.C., Claus, W., Guillard, R.R.L., 1987. Media for the culture of oceanic ultraphytoplankton. J. Phycol. 23, 633-638.

Krock, B., Tillmann, U., John, U., Cembella, A., 2008. LC-MS-MS aboard ship: tandem mass spectrometry in the search for phycotoxins and novel toxigenic plankton from the North Sea. Anal. Bioanal. Chem. 392, 797-803.

Krock, B., Tillmann, U., John, U., Cembella, A.D., 2009. Characterization of azaspiracids in plankton size-fractions and isolation of an azaspiracid-producing dinoflagellate from the North Sea. Harmful Algae 8, 254-263. 
Lassus, P., Amzil, Z., Baron, R., Sechet, V., Barille, L., Abadie, E., Bardouil, M., Sibat, M., Truquet, P., Berard, J.B., Gueguen, M., 2007. Modelling the accumulation of PSP toxins in Thau Lagoon oysters (Crassostrea gigas) from trials using mixed cultures of Alexandrium catenella and Thalassiosira weissflogii. Aquatic Living Resources 20, 59-67.

Lassus, P., Bardouil, M., Baron, R., Berard, J.B., Masselin, P., Truquet, P., Pitrat, J.P., 2005. Improving detoxification efficiency of PSP contaminated oysters (Crassostrea gigas Thunberg). Aquaculture Europe, 3-6.

Lassus, P., Bardouil, M., Massselin, P., Naviner, M., Truquet, P., 2000. Comparative efficiencies of different non-toxic microalgal diets in detoxification of PSP-contaminated oysters (Crassostrea gigas Thunberg). J. Nat. Toxins 9, 1-12.

Magdalena, A.B., Lehane, M., Krys, S., Fernandez, M.L., Furey, A., James, K.J., 2003a. The first identification of azaspiracids in shellfish from France and Spain. Toxicon 42, 105-108.

Magdalena, A.B., Lehane, M., Moroney, C., Furey, A., James, K.J., 2003b. Food safety implications of the distribution of azaspiracids in the tissue compartments of scallops (Pecten maximus). Food. Add. Contam. 20, 154-160.

Marcaillou, C., Haure, J., Mondeguer, F., Courcoux, A., Dupuy, B., Penisson, C., 2010. Effect of food supply on the detoxification in the blue mussel, Mytilus edulis, contaminated by diarrhetic shellfish toxins. Aquatic Living Resources 23, 255-266.

McCarron, P., Kilcoyne, J., Miles, C.O., Hess, P., 2009. Formation of azaspiracids-3, -4, -6, and -9 via decarboxylation of carboxyazaspiracid metabolites from shellfish. J. Agric. Food. Chem. 57, 160-169.

McMahon, T., Silke, J., 1996. West coast of Ireland winter toxicity of unknown aetiology in mussels. Harmful Algae News 14, 2.

Medhioub, W., 2011. Etude des mécanismes de contamination des mollusques bivalves par des neurotoxines à action rapide (FAT) et développement de procédés de détoxification Faculté de science de Tunis et Institut universitaire européen de la mer. Université de Tunis El Mana et Université de Bretagne occidentale, Tunis, pp. 202.

Medhioub, W., Gueguen, M., Lassus, P., Bardouil, M., Truquet, P., Sibat, M., Medhioub, N., Soudant, P., Kraiem, M., Amzil, Z., 2010. Detoxification enhancement in the gymnodiminecontaminated grooved carpet shell, Ruditapes decussatus (Linne). Harmful Algae 9, 200207.

Nicolaou, K.C., Koftis, T.V., Vyskocil, S., Petrovic, G., Ling, T.T., Yamada, Y.M.A., Tang, W.J., Frederick, M.O., 2004. Structural revision and total synthesis of azaspiracid-1, part 2: Definition of the ABCD domain and total synthesis. Angew. Chem. Int. Ed. 43, 4318-4324.

Nzoughet, K.J., Hamilton, J.T.G., Floyd, S.D., Douglas, A., Nelson, J., Devine, L., Elliott, C.T., 2008. Azaspiracid: First evidence of protein binding in shellfish. Toxicon 51, 1255-1263.

O'Driscoll, D., Skrabakova, Z., O'Halloran, J., van Pelt, F., James, K.J., 2011. Mussels increase xenobiotic (azaspiracid) toxicity using a unique bioconversion mechanism. Environ. Sci. Technol. 45, 3102-3108.

Ofuji, K., Satake, M., McMahon, T., James, K.J., Naoki, H., Oshima, Y., Yasumoto, T., 2001. Structures of azaspiracid analogs, azaspiracid-4 and azaspiracid-5, causative toxins of azaspiracid poisoning in Europe. Biosci. Biotechnol., Biochem. 65, 740-742. 
Ofuji, K., Satake, M., McMahon, T., Silke, J., James, K.J., Naoki, H., Oshima, Y., Yasumoto, T., 1999. Two analogs of azaspiracid isolated from mussels, Mytilus edulis, involved in human intoxication in Ireland. Nat. Toxins 7, 99-102.

Pearce, I., Handlinger, J.H., Hallegraeff, G.M., 2005. Histopathology in Pacific oyster (Crassostrea gigas) spat caused by the dinoflagellate Prorocentrum rhathymum. Harmful Algae 4, 61-74.

Potvin, É., Jeong, H.J., Kang, N.S., Tillmann, U., Krock, B., 2011. First Report of the Photosynthetic Dinoflagellate Genus Azadinium in the Pacific Ocean: Morphology and Molecular Characterization of Azadinium cf. poporum. Journal of Eukaryotic Microbiology, n/a-n/a.

Rehmann, N., Hess, P., Quilliam, M.A., 2008. Discovery of new analogs of the marine biotoxin azaspiracid in blue mussels (Mytilus edulis) by ultra-performance liquid chromatography/tandem mass spectrometry. Rapid Commun. Mass Spectrom. 22, 549-558.

Salas, R., Tillmann, U., John, U., Kilcoyne, J., Burson, A., Cantwell, C., Hess, P., Jauffrais, T., Silke, J., 2011. The role of Azadinium spinosum (Dinophyceae) in the production of azaspiracid shellfish poisoning in mussels. Harmful Algae 10, 774-783.

Satake, M., Ofuji, K., Naoki, H., James, K.J., Furey, A., McMahon, T., Silke, J., Yasumoto, T., 1998. Azaspiracid, a new marine toxin having unique spiro ring assemblies, isolated from Irish mussels, Mytilus edulis. J. Am. Chem. Soc. 120, 9967-9968.

Shaw, B.L., Battle, H.I., 1957. The gross and microscopic anatomy of the digestive tract of the oyster Crassostrea virginica (Gmelin). Can. J. Zool. 35, 325-347.

Taleb, H., Vale, P., Amanhir, R., Benhadouch, A., Sagou, R., Chafik, A., 2006. First detection of azaspiracids in mussels in north west Africa. Journal of Shellfish Research 25, 1067-1070.

Tillmann, U., Elbrachter, M., John, U., Krock, B., 2011. A new non-toxic species in the dinoflagellate genus Azadinium: A. poporum sp. nov. Eur. J. Phycol. 46, 74-87.

Tillmann, U., Elbrachter, M., Krock, B., John, U., Cembella, A., 2009. Azadinium spinosum gen. et $\mathrm{sp}$ nov (Dinophyceae) identified as a primary producer of azaspiracid toxins. Eur. J. Phycol. 44, 63-79.

Twiner, M.J., Rehmann, N., Hess, P., Doucette, G.J., 2008. Azaspiracid shellfish poisoning: A review on the chemistry, ecology, and toxicology with an emphasis on human health impacts. Marine Drugs 6, 39-72.

Ueoka, R., Ito, A., Izumikawa, M., Maeda, S., Takagi, M., Shin-Ya, K., Yoshida, M., van Soest, R.W.M., Matsunaga, S., 2009. Isolation of azaspiracid-2 from a marine sponge Echinoclathria sp as a potent cytotoxin. Toxicon 53, 680-684.

Vale, P., R. Bire, and P. Hess. 2008. Confirmation by LC-MS/MS of azaspiracids in shellfish from the Portuguese north-western coast. Toxicon 51 (8):1449-1456.

Villar-Gonzalez, A., Luisa Rodriguez-Velasco, M., Gago-Martinez, A., 2011. Determination of Lipophilic Toxins by LC/MS/MS: Single-Laboratory Validation. J. AOAC Int. 94, 909-922. 
Table 1. MS/MS transitions used for quantification of all AZAs observed.

\begin{tabular}{ccc} 
& Transition 1 & Transition 2 \\
\hline AZA1 & $842.5 / 824.5$ & $842.5 / 672.5$ \\
AZA2 & $856.5 / 838.5$ & $856.5 / 672.5$ \\
AZA3 & $828.5 / 810.5$ & $828.5 / 658.5$ \\
AZA4 & $844.5 / 826.5$ & $844.5 / 658.5$ \\
AZA5 & $844.5 / 826.5$ & $844.5 / 674.5$ \\
AZA6 & $842.5 / 824.5$ & $842.5 / 658.5$ \\
AZA7 & $858.5 / 840.5$ & $858.5 / 672.5$ \\
AZA8 & $858.5 / 840.5$ & $858.5 / 688.5$ \\
AZA9 & $858.5 / 840.5$ & $858.5 / 658.5$ \\
AZA10 & $858.5 / 840.5$ & $858.5 / 674.5$ \\
AZA11 & $872.5 / 854.5$ & $872.5 / 672.5$ \\
AZA12 & $872.5 / 854.5$ & $872.5 / 688.5$ \\
AZA17 & $872.5 / 810.5$ & $872.5 / 658.5$ \\
AZA19 & $886.5 / 824.5$ & $886.5 / 658.5$ \\
AZA21 & $888.5 / 826.5$ & $888.5 / 658.5$ \\
AZA23 & $902.5 / 840.5$ & $902.5 / 658.5$ \\
\hline
\end{tabular}

Table 2. AZA depuration rates $(\mathrm{k})$ in day $^{-1}$ using a 1-compartment model, the adjusted square of correlation coefficient $\left(R^{2}\right)$ from equation 1 . Time in days to reach a $50 \%$ reduction in toxin concentration $(T 1 / 2)$ from equation 3 , for each diet after normalisation of the values and for $A Z A s, A Z A 1+2$ and $A Z A$ metabolites using average value of diet $1-3$, during the detoxification period (day 6-21).

\begin{tabular}{lccc} 
& $\mathrm{k}$ & Adjusted $\mathrm{R}^{2}$ & $\mathrm{~T} 1 / 2$ \\
\hline AZAs diet 1 & -0.07 & 0.48 & 9.9 \\
AZAs diet 2 & -0.06 & 0.80 & 11.6 \\
AZAs diet 3 & -0.05 & 0.57 & 13.9 \\
\hline AZAs & -0.06 & 0.72 & 11.6 \\
AZA1+2 & -0.08 & 0.68 & 8.7 \\
AZA metabolites & -0.05 & 0.79 & 13.9 \\
\hline
\end{tabular}


Table 3. AZA depuration rates $\left(k_{1}\right.$ and $\left.k_{2}\right)$ in day $^{-1}$ and the toxin loss by the first compartment $\left(C_{a}\right)$ using a 2-compartment model, the adjusted square of correlation coefficient $\left(R^{2}\right)$ from equation 2, for total AZAs, AZA1+2, AZA metabolites, and AZA1 and -2 with their respective metabolites during the detoxification period (day 6-21), using average value of diet 1-3 after normalisation of the values.

\begin{tabular}{lcccc} 
& $\mathrm{k}_{1}$ & $\mathrm{k}_{2}$ & $\mathrm{C}_{\mathrm{a}}$ & Adjusted $\mathrm{R}^{2}$ \\
\hline AZAs & -0.87 & -0.03 & 0.38 & 0.96 \\
AZA1+2 & -1.13 & -0.04 & 0.43 & 0.95 \\
AZA metabolites & -0.65 & -0.02 & 0.32 & 0.96 \\
\hline AZA1 + related metabolites & -0.75 & -0.03 & 0.39 & 0.96 \\
AZA2 + related metabolites & -0.72 & -0.03 & 0.35 & 0.98 \\
\hline
\end{tabular}

Table 4. Temporal variation in the proportion of AZA toxins (\%), and AZA toxin concentrations ( $\mu \mathrm{g} \cdot \mathrm{kg}^{-1}$ and $\left.\mu \mathrm{g} \cdot \mathrm{kg}^{-1} \mathrm{AZA} 1 \mathrm{TEQ}\right)$ in whole mussels over time for diet 1 (5000 cells. $\mathrm{mL}^{-1}$ of $A$. spinosum). Underlined in grey are the toxin proportions related to AZA1, in white to $A Z A 2$ and in bold are the four major toxins. TEQ are toxic equivalents (concentrations weighted by their toxic equivalence factor $=T E F) ; T^{-1 E F} F_{A Z A 17}=1.4$ (as AZA17 transforms into 3 after cooking); $\mathrm{TEF}_{\mathrm{AZA19}}=\mathrm{TEF}_{\mathrm{AZA}}=1$ (as $\mathrm{AZA19}$ transforms into AZA6 after cooking, and $\mathrm{TEF}_{\mathrm{AZA}}$ is estimated the same as $\left.\mathrm{TEF}_{\mathrm{AZA1} 1}\right)$.

\begin{tabular}{|c|c|c|c|c|c|c|c|c|c|c|}
\hline & Time (days) & 0.25 & 1 & 2 & 3 & 6 & 7 & 8 & 14 & 21 \\
\hline \multirow{2}{*}{$\begin{array}{r}\text { Algal AZAs } \\
(\%)\end{array}$} & AZA1 & 57.9 & 39.5 & 35.3 & 41.5 & 35.1 & 31.7 & 25.8 & 22.9 & 29.3 \\
\hline & AZA2 & 17.4 & 15.0 & 15.6 & 16.4 & 14.5 & 14.0 & 14.8 & 12.0 & 11.7 \\
\hline \multicolumn{2}{|l|}{ Algal AZAs $\left(\mu g \cdot \mathrm{kg}^{-1}\right)$} & 283.1 & 169.5 & 169.1 & 248.3 & 308.9 & 218.7 & 120.6 & 94.5 & 105.1 \\
\hline \multirow{12}{*}{$\begin{array}{c}\text { AZAs metabolites } \\
(\%)\end{array}$} & AZA3 & 0.3 & 0.6 & 0.6 & 0.5 & 0.7 & 0.8 & 0.7 & 0.7 & 0.7 \\
\hline & AZA4 & 0.0 & 0.0 & 0.2 & 0.5 & 2.0 & 2.5 & 2.3 & 5.2 & 7.3 \\
\hline & AZA5 & 0.0 & 0.7 & 1.1 & 1.1 & 1.5 & 1.9 & 1.8 & 3.9 & 5.3 \\
\hline & AZA6 & 0.8 & 2.1 & 1.9 & 1.8 & 2.3 & 2.5 & 2.4 & 3.6 & 2.8 \\
\hline & AZA7-8 & 2.9 & 2.6 & 1.7 & 2.0 & 2.9 & 2.7 & 1.7 & 1.6 & 1.9 \\
\hline & AZA9 & 0.0 & 0.0 & 0.0 & 0.0 & 0.2 & 0.3 & 0.4 & 0.8 & 1.2 \\
\hline & AZA10 & 0.0 & 0.0 & 0.3 & 0.4 & 0.5 & 0.6 & 0.6 & 1.1 & 1.5 \\
\hline & AZA11-12 & 0.4 & 0.3 & 0.2 & 0.3 & 0.3 & 0.3 & 0.3 & 0.3 & 0.3 \\
\hline & AZA17 & 16.7 & 32.3 & 35.4 & 28.2 & 29.8 & 31.0 & 36.8 & 33.8 & 25.5 \\
\hline & AZA19 & 3.6 & 6.9 & 7.4 & 6.4 & 6.9 & 7.8 & 8.5 & 9.0 & 7.5 \\
\hline & AZA21 & 0.0 & 0.0 & 0.3 & 0.8 & 2.8 & 3.2 & 3.4 & 4.3 & 4.4 \\
\hline & AZA23 & 0.0 & 0.0 & 0.0 & 0.1 & 0.4 & 0.5 & 0.6 & 0.7 & 0.8 \\
\hline \multicolumn{2}{|c|}{$\overline{A Z A s}$ metabolites $\left(\mu \mathrm{g} \cdot \mathrm{kg}^{-1}\right)$} & 93.0 & 141.0 & 163.3 & 180.7 & 313.9 & 258.9 & 176.6 & 176.7 & 151.5 \\
\hline \multicolumn{2}{|l|}{$\overline{A Z A \text { total }\left(\mu g \cdot \mathrm{kg}^{-1}\right)}$} & 376.1 & 310.5 & 332.4 & 429.0 & 622.8 & 477.7 & 297.2 & 271.2 & 256.6 \\
\hline \multicolumn{2}{|c|}{$\begin{array}{l}\text { Regulated AZAs (AZA1-3) } \\
\left(\mu g . \mathrm{kg}^{-1} \text { AZA1 TEQ) }\right.\end{array}$} & 336.9 & 209.3 & 213.5 & 307.8 & 387.2 & 277.4 & 158.7 & 123.3 & 131.7 \\
\hline \multicolumn{2}{|c|}{$\begin{array}{l}A Z A s 1,2,3,6,17 \text { and } 19 \\
\left(\mu g . \mathrm{kg}^{-1} \text { AZA1 TEQ }\right)\end{array}$} & 441.6 & 377.6 & 409.4 & 512.5 & 704.5 & 534.2 & 344.3 & 285.9 & 249.6 \\
\hline
\end{tabular}


Table 5. Temporal variation in the proportion of AZA toxins (\%), and total AZA toxin contents ( $\mu \mathrm{g} . \mathrm{kg}^{-1}$ of Digestive Gland or Remaining Flesh or Total Flesh) in mussels at the end of the contamination and detoxification period for diet 1 (5000 cells. $\mathrm{mL}^{-1}$ of $A$. spinosum). Underlined in grey are the four major AZAs.

\begin{tabular}{|c|c|c|c|c|c|}
\hline & & $\begin{array}{l}\text { Digestive gland } \\
\text { (Day 7) }\end{array}$ & $\begin{array}{l}\text { Digestive gland } \\
\text { (Day 21) }\end{array}$ & $\begin{array}{c}\text { Remaining Flesh } \\
\text { (Day 7) }\end{array}$ & $\begin{array}{c}\text { Remaining Flesh } \\
\text { (Day 21) }\end{array}$ \\
\hline \multirow{2}{*}{$\begin{array}{c}\text { Algal AZAs } \\
\text { (\%) }\end{array}$} & AZA1 & 29.2 & 40.4 & 27.1 & 19.8 \\
\hline & AZA2 & 15.6 & 14.0 & 12.0 & 10.4 \\
\hline \multirow{6}{*}{$\begin{array}{c}\text { AZAs } \\
\text { metabolites }\end{array}$} & AZA3 & 0.4 & 0.6 & 0.8 & 1.0 \\
\hline & AZA4 & 2.0 & 5.7 & 1.3 & 2.3 \\
\hline & AZA5 & 2.3 & 4.2 & 1.6 & 2.2 \\
\hline & AZA6 & 2.6 & 2.1 & 2.3 & 3.4 \\
\hline & AZA7-8 & 2.6 & 2.0 & 2.0 & 0.8 \\
\hline & AZA9 & 0.3 & 0.8 & 0.0 & 0.0 \\
\hline \multirow{6}{*}{ (\%) } & AZA10 & 0.4 & 1.3 & 0.0 & 0.0 \\
\hline & AZA11-12 & 0.3 & 0.2 & 0.0 & 0.0 \\
\hline & AZA17 & 29.1 & 17.3 & 42.3 & 47.1 \\
\hline & AZA19 & 9.3 & 6.1 & 8.0 & 10.5 \\
\hline & AZA21 & 4.9 & 4.4 & 2.1 & 2.0 \\
\hline & AZA23 & 0.9 & 0.8 & 0.4 & 0.4 \\
\hline \multicolumn{2}{|c|}{$\begin{array}{c}\text { AZA total } \\
\left(\mu \mathrm{g} \cdot \mathrm{kg}^{-1} \mathrm{DG} \text { or } \mathrm{RF}\right)\end{array}$} & $2673.1 \pm 44.1$ & $1153.7 \pm 21.6$ & $193.1 \pm 3.5$ & $111.3 \pm 1.6$ \\
\hline \multicolumn{2}{|c|}{$\begin{array}{l}\text { AZA total }\left(\mu \mathrm{g} . \mathrm{kg}^{-1} \mathrm{TF}\right) \\
\text { weight standardised }\end{array}$} & $336.9 \pm 5.6$ & $208.1 \pm 17.7$ & $168.8 \pm 3.1$ & $91.3 \pm 1.3$ \\
\hline
\end{tabular}

Table 6. AZA concentration in different mussel tissues after exposure for $24 \mathrm{~h}$ ( 3 analyses of pools of 30 individuals for each tissue type, TF = Total Flesh, DG = Digestive Gland, RF = Remaining Flesh, $\mathrm{MM}=$ Mantle Margin, $\mathrm{M}=$ Mantle, $\mathrm{LP}=$ Labial Palp, PAM = Posterior Adductor Muscle) and proportion of each tissue in mussels analysed.

\begin{tabular}{lccccccccc} 
AZA $\left(\boldsymbol{\mu g} \cdot \mathbf{k g}^{-1}\right)$ & TF & DG & RF & Gills & MM & LP & M & PAM & Foot \\
\hline AZA1 & 189 & 836 & 76 & 89 & 30 & 64 & 29 & 14 & 19 \\
AZA2 & 61 & 301 & 22 & 25 & 8 & 19 & 7 & 3 & 5 \\
AZA3 & 4 & 18 & 2 & 2 & 0 & 0 & 0 & 0 & 0 \\
AZA4 & 4 & 29 & 2 & 0 & 0 & 0 & 0 & 0 & 0 \\
AZA5 & 6 & 43 & 4 & 2 & 1 & 2 & 2 & 1 & 1 \\
AZA6 & 12 & 51 & 5 & 5 & 1 & 0 & 1 & 1 & 0 \\
AZA8 & 21 & 117 & 11 & 4 & 3 & 5 & 4 & 2 & 3 \\
AZA11-12 & 3 & 17 & 1 & 0 & 0 & 0 & 0 & 0 & 0 \\
AZA17 & 178 & 723 & 105 & 117 & 29 & 77 & 36 & 22 & 16 \\
AZA19 & 36 & 161 & 21 & 21 & 4 & 14 & 6 & 4 & 3 \\
AZA21 & 3 & 20 & 2 & 0 & 0 & 0 & 0 & 0 & 0 \\
AZA23 & 0 & 4 & 0 & 0 & 0 & 0 & 0 & 0 & 0 \\
\hline Total AZAs & 517 & 2319 & 251 & 264 & 77 & 182 & 85 & 48 & 46 \\
\hline Tissue \% & 100 & 16 & 22 & 16 & 17 & 4 & 10 & 10 & 7 \\
of total wet flesh & & & & & & & & &
\end{tabular}


Table 7. Mortality (\%) observed in the different conditions at the end of the contamination and decontamination period.

\begin{tabular}{lcccc}
\multicolumn{1}{c}{ Mortality (\%) } & Diet 1 & Diet 2 & Diet 3 & Control \\
\hline Contamination (day 0-7) & 1.2 & 7.0 & 2.7 & 0.5 \\
Detoxification (day 7-21) & 6.6 & 4.6 & 2.9 & 1.5 \\
Total & 8 & 12 & 6 & 2 \\
\hline
\end{tabular}

\section{Figures}

Figure 1. Total AZA toxin concentration ( \pm std) in mussels ( 3 analyses of 10 pooled mussels) in $\mu \mathrm{g} \cdot \mathrm{kg}^{-1}$ of wet flesh (sum of all analogue concentrations quantified against AZA1) during contamination (Day 0-7) and detoxification (Day 7-21) from the four experimental treatments (Diet $1=5000$ cells. $\mathrm{mL}^{-1}$ of $A$. spinosum, Diet $2=10000$ cells. $\mathrm{mL}^{-1}$ of $A$. spinosum, Diet 3 $=5000$ cells $\mathrm{mL}^{-1}$ of respectively $A$. spinosum and T-Iso, and control $=10000$ cells. $\mathrm{mL}^{-1}$ of $\mathrm{T}$-Iso). Horizontal dash line represents AZA regulatory limit for shellfish (160 $\mu \mathrm{g}^{\mathrm{kg}}{ }^{-1} \mathrm{AZA} 1$ TEQ).

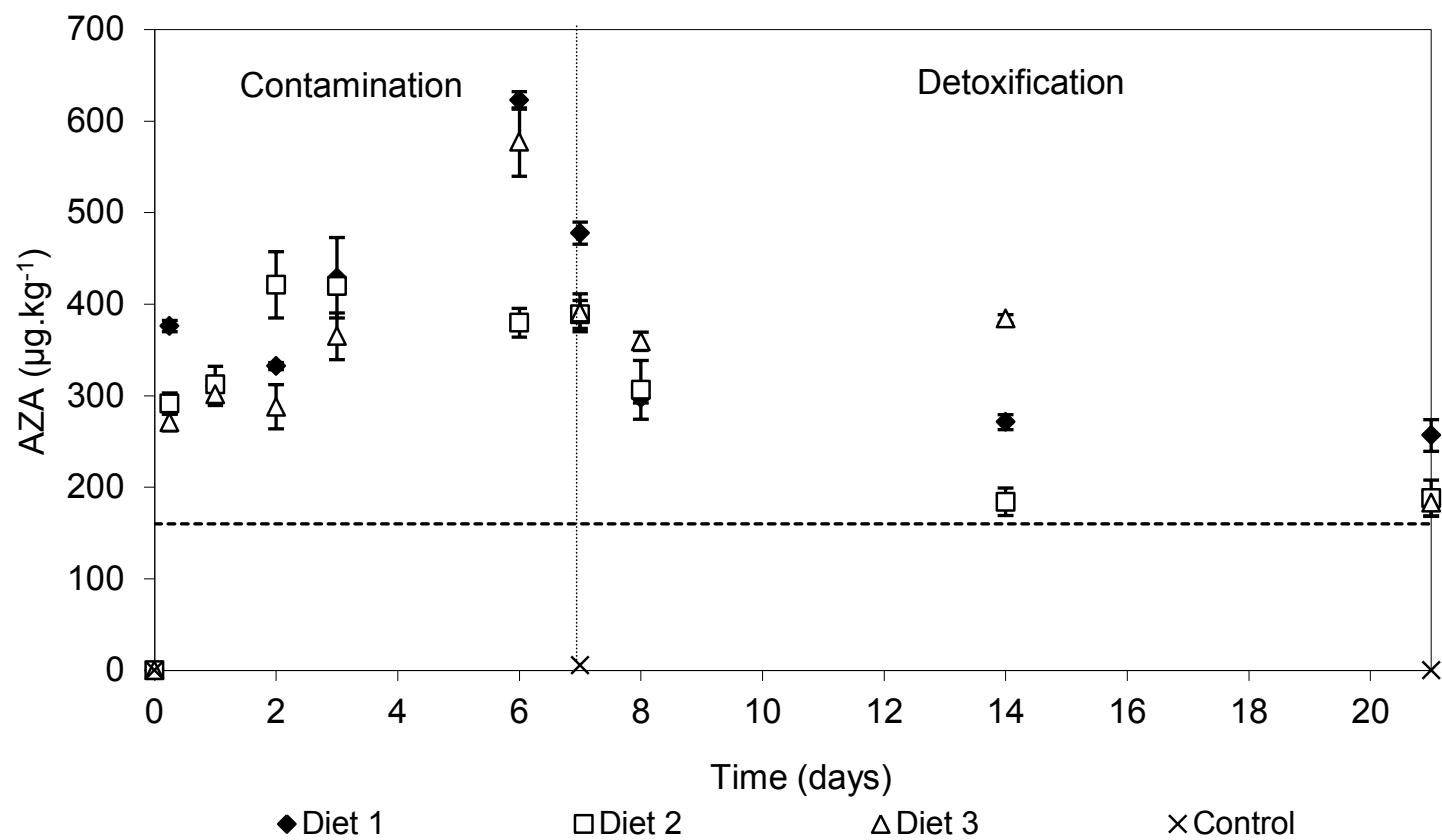


Figure 2. AZA detoxification kinetics, (a) total AZAs, (b) AZA1+2 and AZAs metabolites and (c) AZA1or AZA2 plus their related AZAs, during the detoxification period (day 6-21, a, b, c correspond to averaged normalised values for all 3 diets, 2-compartment model).
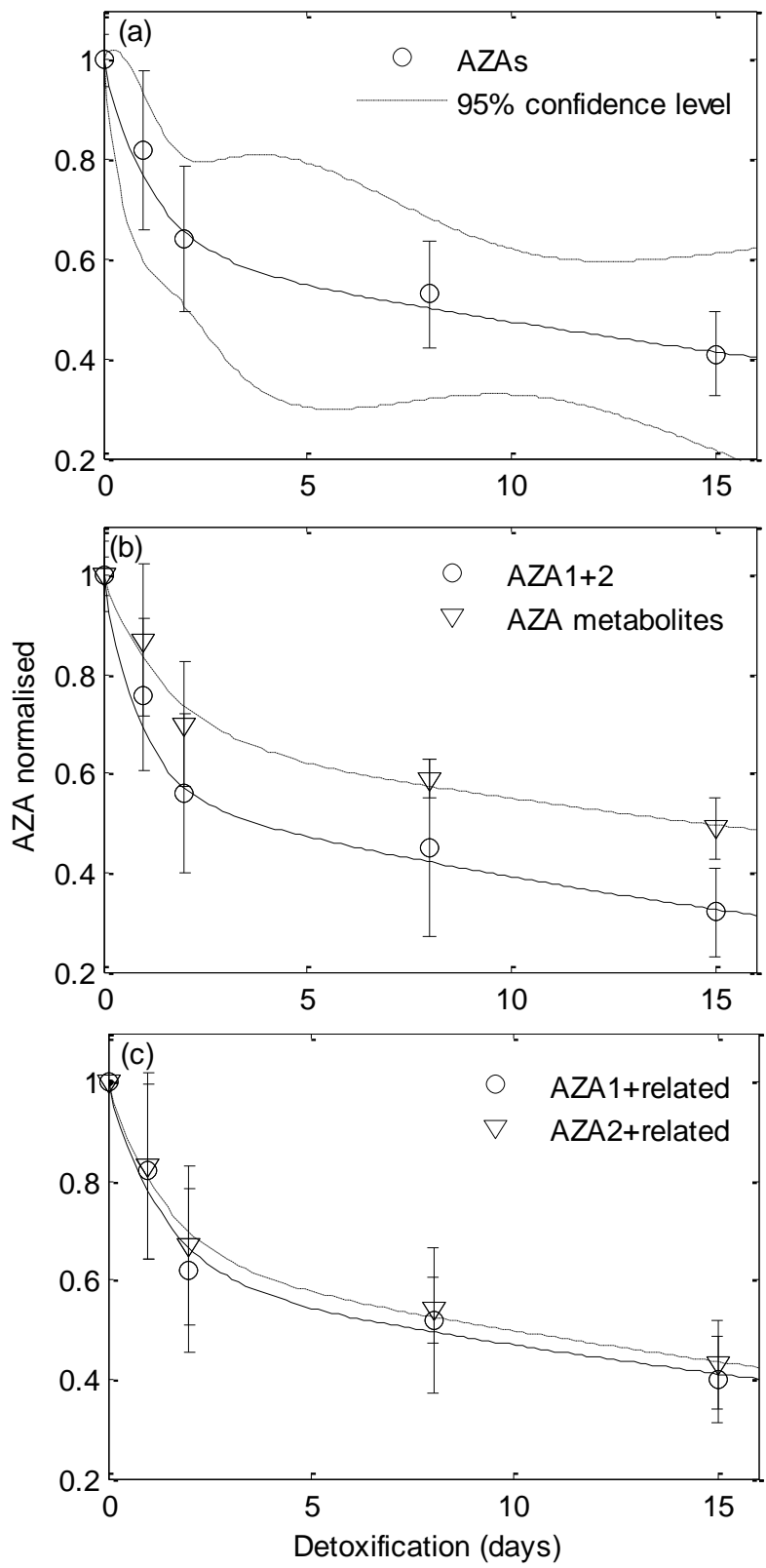
Figure 3. Variation of AZA1 and -2 from A. spinosum compared to AZA metabolites in total flesh $(a, b, c)$, digestive gland $(d, e, f)$ and remaining flesh $(g, h, i)$ as a function of time in diet $1(a, d, g)$, diet $2(b, e, h)$, diet $3(c, f, i)$.
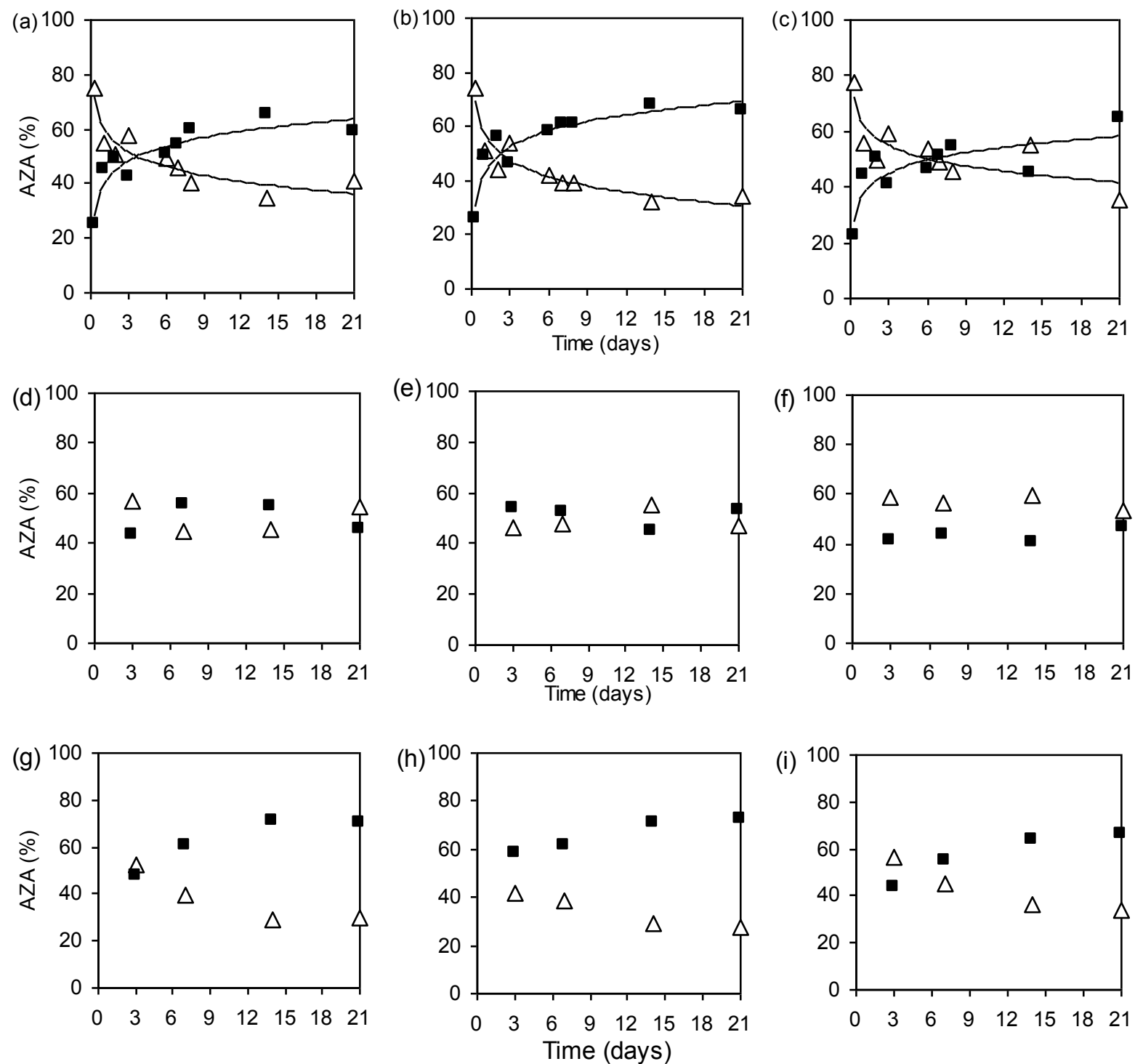

$\triangle \mathrm{AZAs}$ (A. spinosum)

- AZAs (metabolites) 
Figure 4. AZA structure, $m / z[m+H]^{+}$detected in shellfish and possible biotransformation pathways in $M$. edulis of AZA1 (a) and -2 (b) observed during the feeding experiment with $A$. spinosum. Underlined in grey are the toxins related to AZA1, in white to AZA2, and AZAs with * were below the limit of detection.

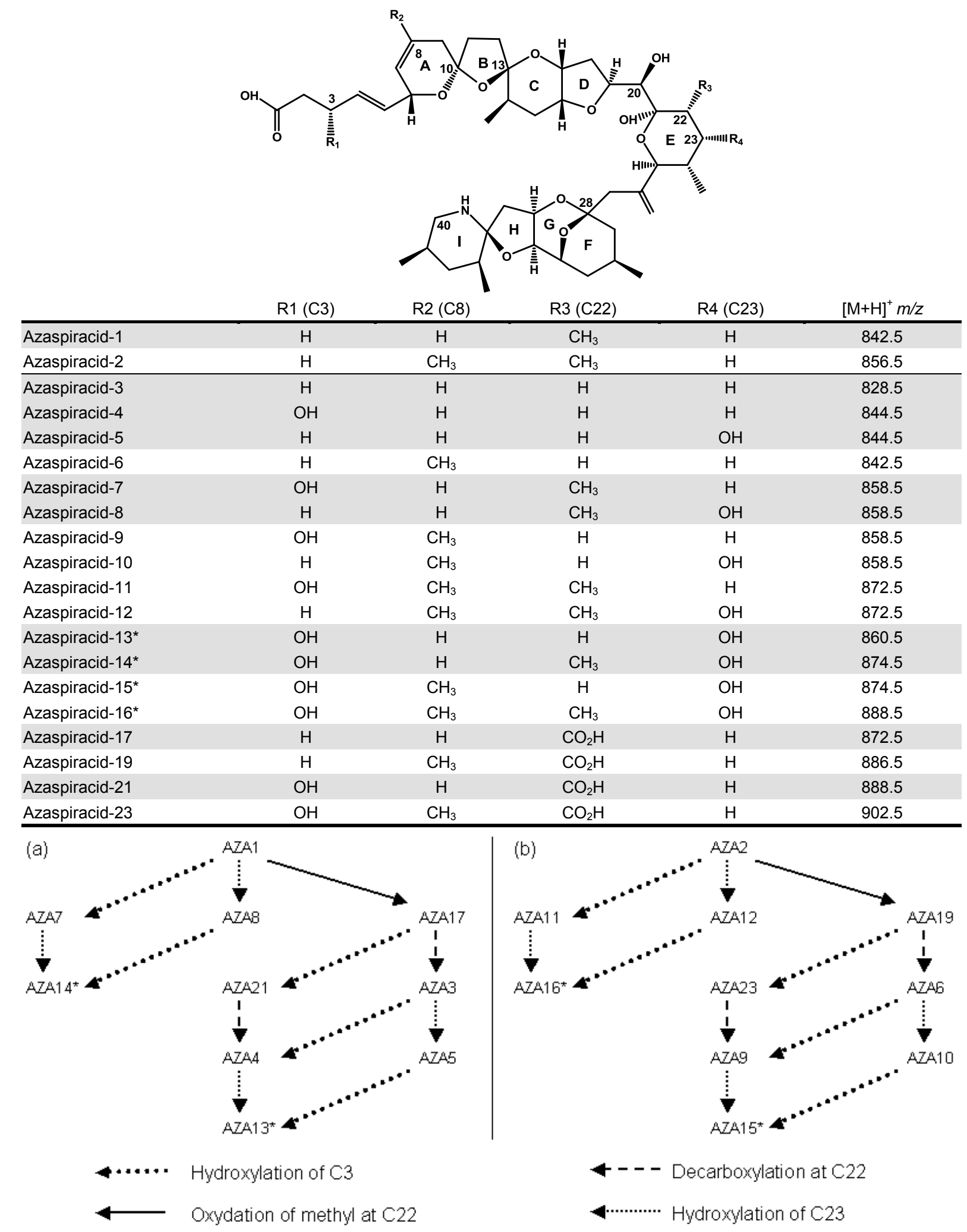


Figure 5. AZA profile and distribution in different mussel tissues over $24 \mathrm{~h}$ ( 3 analyses of pools of 30 individuals for each tissue type, TF = Total Flesh, DG = Digestive Gland, RF = Remaining Flesh, $\mathrm{MM}=$ Mantle Margin, $\mathrm{M}=$ Mantle, $\mathrm{LP}=$ Labial Palp, PAM = Posterior Adductor Muscle).

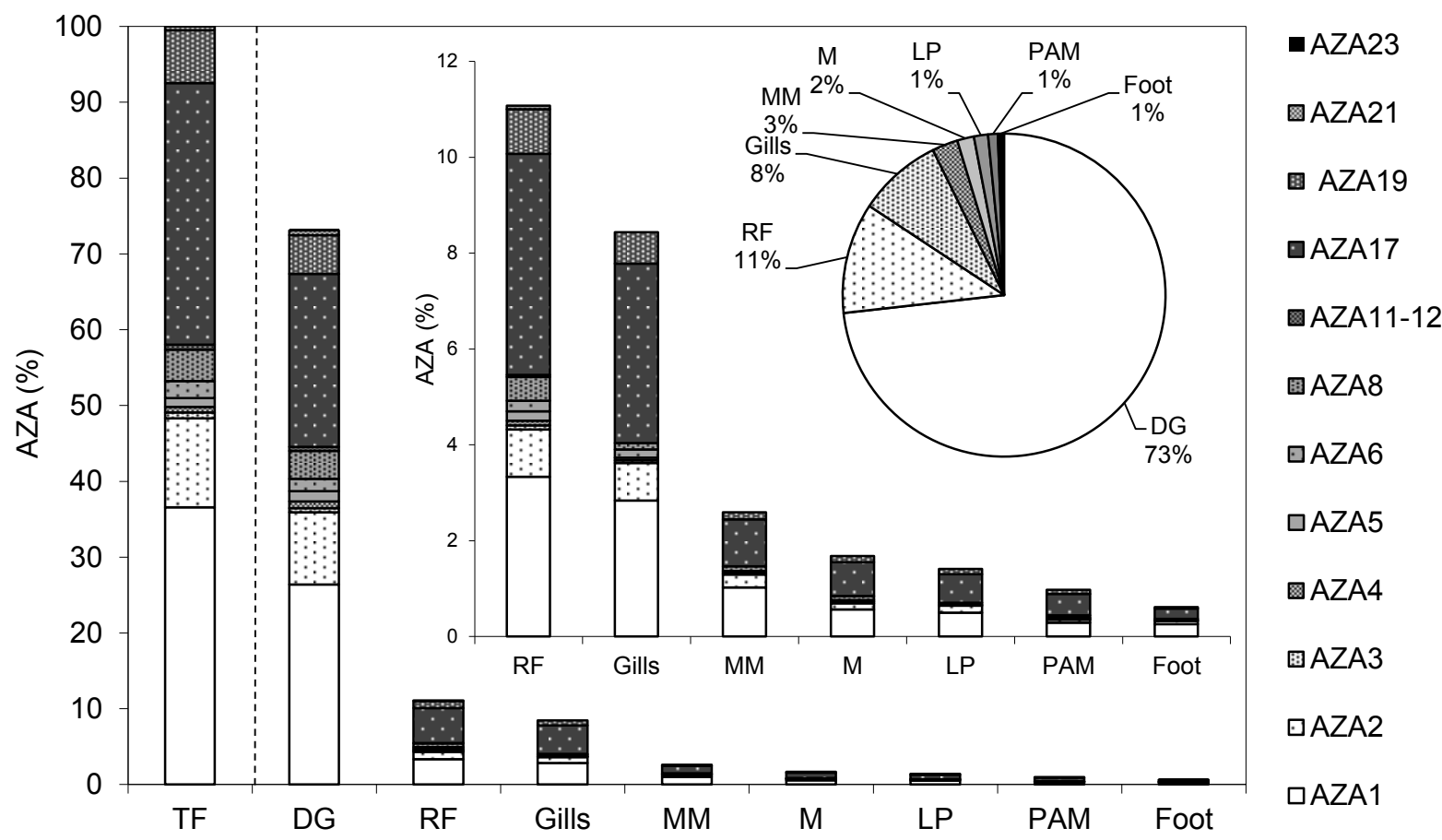

Figure 6. Evolution of the digestive gland tubule thickness $(\mu \mathrm{m})$ in toxic $(A$. spinosum) and non-toxic control (T-Iso) diets during contamination (days 2 and 7 ) and at the end of the detoxification period (day 21). The errors bars represent the standard deviation $(n \geq 150$ digestive tubules). Values with different letters are statistically different at $P<0.05$.

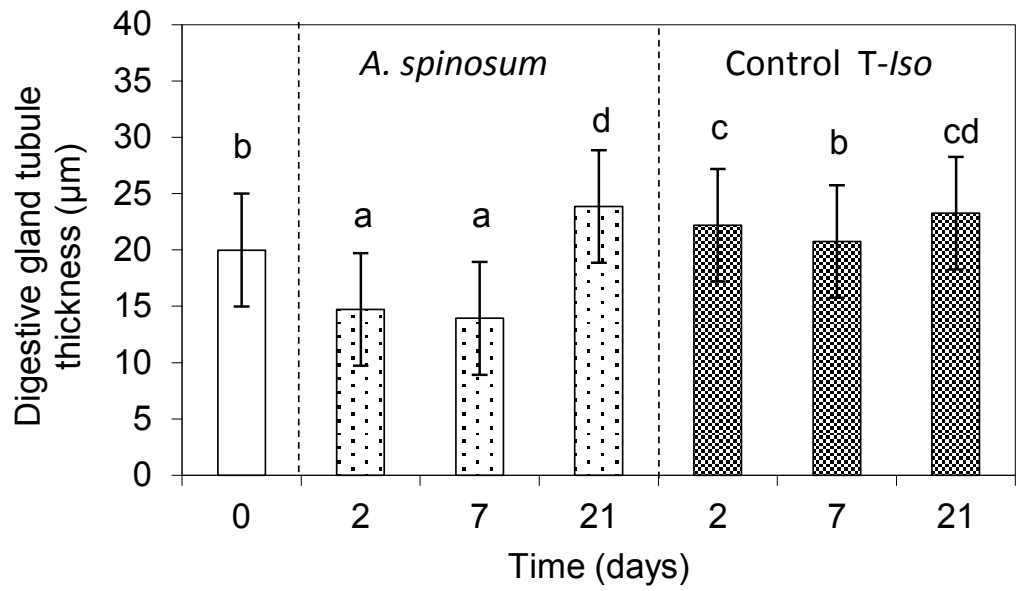

